\title{
ПИКОСЕКУНДНЫЕ ЛАЗЕРНЫЕ ДИОДНЫЕ ИЗЛУЧАТЕЛИ
}

\author{
(C) 2021 г. Е. С. Воропай, Ф. А. Ермалицкий*, \\ А. Е. Радько, М. П. Самцов \\ *e-mail:f.ermalitski@gmail.com \\ Поступила в редакцию 20.10.2020 г. \\ После доработки 30.10.2020 г. \\ Принята к публикации 31.10.2020 г.
}

DOI: $10.31857 / \mathrm{S} 0032816221020245$

Излучатели предназначены для различных оптоэлектронных устройств, где необходимы повторяющиеся короткие световые импульсы. Они могут быть использованы во флуорометрии (как источники возбуждения при измерениях кинетики различных видов люминесценции), дальнометрии (в качестве зондирующих излучателей), импульсной спектрометрии и т.д.

Источники света состоят из блока оптического излучателя и внешнего блока питания. Оптические излучатели могут работать в режимах как внутреннего, так и внешнего запусков. Достоинствами приборов являются компактность, а также низкие уровни питания (12 В) и потребляемой мощности (3 Вт).

Блок оптического излучателя включает в себя задающий кварцевый генератор на основе микроконтроллера, цепь синхронизации, низковольтный формирователь субнаносекундных электрических импульсов, цепь накачки диодов на основе подстраиваемого источника постоянного тока и светоизлучатель - лазерный диод. Предусмотрена возможность термостабилизации выходного каскада цепи накачки и лазерного диода. Данный блок может также использоваться для накачки суб- и наносекундных светодиодов. Задающий кварцевый генератор с базовой частотой 20 (или 80) МГц управляется микроконтроллером, который выдает дискретные кварцованные частоты в диапазоне 0-20 МГц. Наличие многочастотного режима позволяет в случае флуорометрии легко сочетать измерительные режимы прямой и обращенной шкал.

Специальная цепь формирует импульсы синхронизации для используемых устройств регистрации. Она дает возможность при необходимости вводить дополнительную задержку светового сигнала относительно импульса синхронизации. Цепь синхронизации позволяет блоку также работать с внешними управляющими сигналами с частотами до 10 МГц.
Низковольтный формирователь вырабатывает наносекундный перепад напряжения до 12 В, который цепью дифференцирования преобразуется в импульс напряжения длительностью менее 1 нс. После инвертирования данный импульс через эмиттерный повторитель поступает непосредственно на лазерный диод. Для оптимизации режима работы лазерных диодов имеется регулируемый источник постоянного тока.

Задание параметров излучаемых световых импульсов - длительности и световой мощности для лазерных диодов каждого типа обеспечивается подбором тока накачки и напряжения смещения. Для повышения многофункциональности излучателей предусмотрены 2 режима: пикорежим (минимизированной надпороговой накачки) с генерацией лазерных импульсов длительностью 70-180 пс и нанорежим (стандартной им-

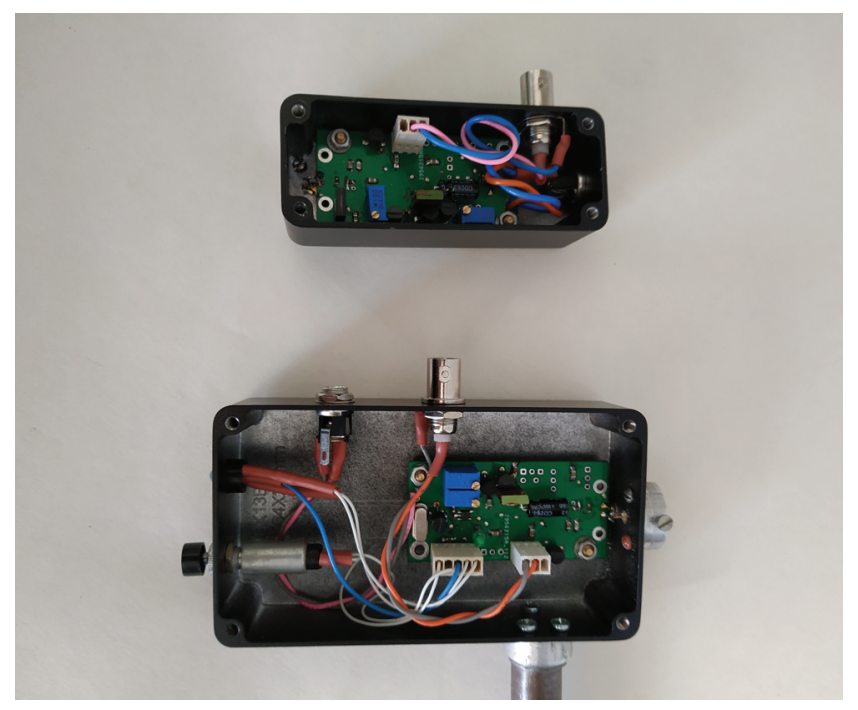

Рис. 1. Общий вид лазерных диодных излучателей (со снятыми крышками) в двух различных металлических корпусах. 
пульсной накачки) с увеличенной в 50-100 раз световой мощностью и длительностью импульсов $1-1.2$ нс.

В качестве светоизлучающих элементов используются доступные серийные лазерные диоды фирм SONY, SONYO, FUJI, SHARP и др.

Наружный сетевой блок-адаптер 220 В/12 B × $\times 0.25$ А (обычно промышленного производства) обеспечивает излучатель необходимым напряжением питания $12 \mathrm{~B}$.

Технические характеристики пикосекундных лазерных диодных излучателей. Длины волн излучения от 405 до 808 нм; длительность лазерных импульсов на полувысоте (измеренных стрик-камерой Hamamatsu C 4334 с разрешением 25 пс) для ряда длин волн в пикорежиме (минимизированной надпороговой накачки) составляет: для $405 \mathrm{Hм}$ - от 70 пс, для $520 \mathrm{нм}$ - от 130 пс, для 650 нм - от 90 пс, для 780 нм - от 180 пс; а в нано- режиме (стандартной импульсной накачки) длительность равна 1-1.2 нс для всех длин волн. Средняя световая мощность до 10 мВт. Частоты следования световых импульсов: при внутреннем запуске до 20 (или 80) МГц, при внешнем - до 10 МГц. Типичные размеры блока излучателя $115 \times 64 \times 30$ мм и $80 \times 55 \times 25$ мм при габаритах электронной платы $60 \times 30 \times 20$ мм. Питание от серийного блока питания $220 \mathrm{~B} / 12 \mathrm{~B} \times 0.25 \mathrm{~A}$, потребляемая мощность 3 Вт. Масса 0.2 кг.

Общий вид лазерных диодных излучателей (со снятыми крышками) в двух различных металлических корпусах приведен на рис. 1.

Адрес для справок: Республика Беларусь, 220045, Минск, ул. Курчатова, 7, Научно-исследовательское учреждение "Институт прикладных физических проблем имени А.Н. Севченко” (НИИПФП им. А.Н. Севченко БГУ); тел. +375-29-111-31-83, факс: +375-17-398-03-31;e-mail:f.ermalitski@gmail.com 